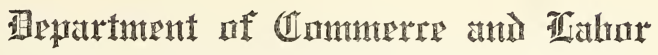 \\ BUREAU OF STANDARDS
}

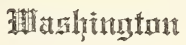

Bureau Circular No. 3

December 10, 1903.

Under the provisions of an act of Congress approved March 3, 1901, establishing the Bureau of Standards, this Bureau is authorized, among other things, to compare standards of mass used in scientific work, manufacturing, and commerce with the standards of the Government. For the present the work of the Bureau will be limited to the verification of masses within the following limits: 0.01 grain to 50 pounds avoirdupois or from 0.1 milligram to 20 kilograms.

FEES.

The following schedule of fees for verification of standards of mass have been established:

SCHEDULE 11.-PRECISION STANDARDS OF MASS.

A standard of mass to be accepted as a precision standard must fulfill the following requirements: (1) It must be made of a single piece of nonoxidizable metal or of a single piece of metal plated with a nonoxidizable metal, and (2) its form and finish must be such as to readily show accidental or intentional alterations of its mass.

Standards of precision are limited to those whose masses are between 1 grain and 1 kilogram.

(a) Verification of a single mass of known density

(b) Determination of density, for each mass _ . . . .

(c) Verification of a connected series of masses, each . _

SCHEDULE 1\%.-ORDINARY STANDARDS OF MASS.

Under this head are included such standards as are used by chemists, assayers, manufacturers, and others.

(a) Verification of masses within the limits of 2 pounds and 50 pounds avoirdupois or between 1 kilogram and 20 kilograms _... . .

(b) Verification of single masses between the limits of 0.01 grain and 1 pound avoirdupois or between 0.1

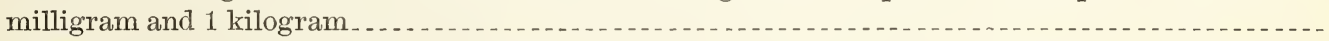

(c) Verification of a connected series of masses, the largest being 1 pound avoirdupois or 1 kilogram or less, each

Remittances. - Fees should be sent with the request for the test in accordance with the above schedules, and should be remitted by money order drawn to the order of the "Bureau of Standards." Delays in forwarding fees involve corresponding delays in the return of articles tested, as the articles are held until the fees due thereon have been paid.

\section{SHIPPING DIRECTIONS.}

Instruments should be securely packed in cases or packages which may be used in returning them to the owner. In all cases transportation charges are payable by the party desiring the test, and should be prepaid.

Address.-Articles should be addressed "Bureau of Standards, Department of Commerce and Labor, Washington, D. C.," and not to members of the Bureau staff. Delays incident to other forms of address will thus be avoided. Articles delivered in person or by 
messenger should be left at the office of the Bureau and should be accompanied by a written request for the verification.

\section{CERTIFICATE.}

The certificate furnished by the Bureau of Standards will contain the following data:

(a) Description and identification marks of article.

(b) Name of party for whom comparison is made.

(c) Temperature and other conditions of the test.

(d) Corrected values or table of corrections desired.

(e) Date of certification.

$(f)$ Seal of the Bureau and signature of the Director.

(h) Special remarks where necessary.

It is the desire of the Burean to cooperate with manufacturers, scientists, and others in bringing about more satisfactory conditions relative to weights and measures in the broader meaning of the term, and to place at the disposal of those interested such information relative to these subjects as may be in its possession.

All communications should be addressed "Bureau of Standards, Department of Commerce and Labor, Washington, D. C."

S. W. Stratton,

Director.

Approved:

Geo. B. Contelyou,

Secretary. 